\title{
THE
}

2003

\section{Mark Twain and "The Awful German Language"}

Norbert Hedderich

University of Rhode Island, hedderich@uri.edu

Follow this and additional works at: https://digitalcommons.uri.edu/ml_facpubs

This is a pre-publication author manuscript of the final, published article.

Terms of Use

All rights reserved under copyright.

\section{Citation/Publisher Attribution}

Hedderich, Norbert. "Mark Twain and "The Awful German Language"." Die Unterrichtspraxis / Teaching German 36, no. 1 (2003): 28-33. doi:10.2307/3531681. JSTOR, www.jstor.org/stable/3531681.

This Article is brought to you for free and open access by the Modern and Classical Languages and Literatures at DigitalCommons@URI. It has been accepted for inclusion in Modern and Classical Languages and Literatures Faculty Publications by an authorized administrator of DigitalCommons@URI. For more information, please contact digitalcommons-group@uri.edu. 


\section{Mark Twain and The Awful German Language}

\section{Background}

Mark Twain (1835-1910) was a uniquely American author who spent a significant amount of time outside the United States. Not only was he one of the most widely traveled people of his period; together with his family he often took up residence abroad for months or years at a time. All of these extended stays took place during the often tumultuous last three decades of his life. For much of the 1890's, for example, the Clemens family moved from one European city to another. Beginning in 1878, this life abroad was born out of necessity rather than enthusiasm for foreign countries. The Clemens family went overseas for a number of reasons. The German spas were to improve his wife Olivia's poor health, the social obligations of their extravagant Hartford, Connecticut, household had become a strain which kept Twain from writing, extensive travel was to provide new material for travel books, and finally, during the long overseas stay of the 1890's, Twain sought to get away from his disastrous financial situation at home. The German-speaking countries took on a central role in these stays abroad. Krumpelmann lists three "German periods" of the Clemens family. Their first was in 1878, when they spent seven weeks in Heidelberg and four months in Munich. Between 1891 and 1893 they made repeated trips to 
Germany and took up residence in Berlin from October 1891 to March 1892, and finally they were in Vienna from September 1897 to May of 1899 (Krumpelmann 10).

Twain's exposure to German and his attempts to learn the language have been fairly well documented by Kersten, Krumpelmann and Thomas. Twain came in contact with German early on in his life. His home state of Missouri had a sizable percentage of German immigrants and earliest reports indicate he attempted to learn the language from two German immigrants in Hannibal, Missouri (Krumpelmann 1). At age 18 he moved to St. Louis to work as a journeyman for various newspapers, including the Anzeiger des Westens, the largest German language newspaper in the West at the time. The same year Twain arrived in St. Louis, the Anzeiger started an English language edition for which the young Samuel Clemens set type (Kersten 19). It was probably here at the Anzeiger that he was first exposed to written German and where he developed his later interest in many features of German, such as compound nouns. None of these early exposures to German led to any proficiency in the language.

More than two decades later, in 1878, now an accomplished writer, Twain began a more serious attempt at learning German in preparation for his first extended stay in Germany. It was the beginning of a twenty-year 
love-hate relationship with the language. Despite repeated efforts, he never reached a level of proficiency that was satisfactory to him. In her insightful article "Mark Twain's German Language Learning Experience," Thomas sheds some light on the matter by analyzing the textbooks he had at his disposal. They presented the grammar-translation method in its purest form, frequently sequenced grammatical items in an illogical manner and insisted on complete presentation of grammatical paradigms. In The Awful German Language Twain makes two comments on the methodology of his instructional materials. Having worked through elaborate presentations of rules, which exceed anyone's memory capacities, the reader "turns over the page and reads, 'Let the pupil make careful note of the following exceptions. 'He runs his eye down and finds that there are more exceptions to the rule than instances of it" (290). In his second comment he ridicules contrived dialogues, a long time feature of foreign language textbooks:

For instance, my book inquires after a certain bird (it is always inquiring after things, which are of no sort of consequence to anybody): "Where is the bird? “ Now the answer to this question, - according to the book, - is that the bird is waiting in the blacksmith shop on account of the rain. Of course no bird would do that, but then you must stick to the book (290-291). 
One needs to keep in mind that Twain had only a few weeks of formal German language instruction and his preferred method of self-study eliminated meaningful listening and speaking practice. Also, he had little opportunity to truly immerse himself in the language, even during the extended stays in Germany. His family was with him, he needed to focus on writing the travel books under contract with his publishers and - this holds true for the second and third German period - his celebrity status brought him into frequent contact with members of German society whose conversational English was superior to his German. According to most reports, by the end of the twenty-year period, he reached more advanced stages of proficiency in reading and listening to German, and was much less successful with speaking "He could speak simple German haltingly and probably ungrammatically" (Krumpelmann 13). His attempts at writing in German, as he did in various letters and in a three act comedy entitled "Meisterschaft," present a curious mix of English and German.

\section{The Essay}

The essay "The Awful German Language", published as Appendix D in a A Tramp Abroad in 1879, is the product of Twain's first German period. Despite later references about German in his notes and letters the 
essay remains his single most important comment on the subject. Why did Twain write this essay? First of all, he needed to write extensively for $A$ Tramp Abroad. He did so by putting to pen his observations on a wide range of topics, which make the book a motley and, at times, disjointed collection of diary entries, newspaper reports, retelling of German folklore and more. There were some aspects of German culture Twain could not relate to, such as Wagner operas; and he lets the reader know in no uncertain terms how he felt about them. There was, however, one thing Twain could always relate to and that was language. He achieved literary fame by stripping the English language of its ornamentation in a novel way. As a former journalist and now an author, he was keenly interested in all matters of language. Therefore, it comes as no surprise that he took a particularly close look at the language of the country he spent so much time in. And just as he compared much of what he observed with the U.S., he compared the findings of his analysis of the German with his main tool - the English language.

The timeless humor and satire of "The Awful German Language" have made it one the most entertaining accounts ever written about a foreign language. The essay reflects Twain's ongoing frustrations with German. While the humor is omnipresent, there is a serious side to the essay. It demonstrates that Twain was an astute observer. He correctly understood the 
salient features of the language despite his limited proficiency and next to no formal instruction

The bulk of the essay is devoted to his observation of those aspects of German most puzzling to him. This section forms about four fifths of the essay. In addition, there is a small and often overlooked section on what Twain likes about German and finally he sums up with a third section entitled "Suggested Reforms." Following is a closer look at all three parts of the essay. Discussion of the first section will be divided into Twain's observations concerning morphological, syntactic, and lexical features of German. He makes next to no comments about phonetic features.

\section{Remarks on Morphological Features}

Considering the near exclusive focus on form in the instructional materials at his disposal, it is not surprising that comments on aspects of form present an important portion of his 'grievances.' Beginning with the third paragraph of the essay, Twain vents his experiences with "these four confusing cases." He was frustrated by the difference in inflectional morphology between the two languages. Whereas the German noun phrase can take four cases, in English three of them, the nominative, accusative and dative are collapsed into one form, with only the genitive retaining a 
separate marker. If we take his comments here at face value, Twain was overwhelmed with the forms of the case system without ever learning its overall purpose.

Twain devotes another major section of his essay to the issue of grammatical gender, undoubtedly a challenging aspect of German. In this matter some important help is available to the learner in the form of gender identification by noun endings. We don't know if Twain was aware of this tool, he might have deduced some of the patterns himself. Therefore, the variability of the German definite article in contrast with the invariability of its English counterpart and the influence of grammatical gender on pronouns in German caused him considerable headaches. As an example, he picks the neuter grammatical gender of $\mathrm{Weib} /$ wife (now obsolete). It provided ample material for his pen, as the following excerpt shows:

In the German it is true that by some oversight of the inventor of the language, a Woman is a female; but a Wife (Weib) is not, - which is unfortunate. A Wife, here, has no sex; she is neuter; so, according to the grammar, a fish is he, his scales are she, but a fishwife is neither (296).

Perhaps Twain did not know that usage of the term Weib was entering its present-day restricted meaning. He did not know, or ignored the fact, that other terms denoting a female spouse do follow the natural gender (Frau, 
Gattin, Gemahlin). But the "Awful German Language" is not a scientific paper. It stems from the pen of one of America's foremost humorists and exaggeration is the driving force behind his humor. To illustrate his point, Twain finishes this section with "Tale of the Fishwife and Its Sad Fate", in which he imposes German gender rules onto English (297).

The other major morphological aspect Twain addresses is adjective endings. It is of little comfort to him that Old English had an inflectional system similar to the one of present day German. As in most of his observations of German, he is looking for logic and purpose in specific structures of the language. And so he rails against the retention of the inflectional system with the German adjective, compared to the reduced single form in English.

Now observe the adjective. Here was a case where simplicity would have been an advantage, therefore, for no other reason, the inventor of this language complicated it all he could. When we wish to speak of our "good friend or friends," in our enlightened tongue, we stick to the one form and have not trouble or hard feeling about it. But with the German tongue it is different. When a German gets his hand on an adjective, he declines it, and keeps on declining it until the common sense is all declined out of it. It is as bad as Latin (294). 


\section{Remarks on Syntactical Features}

By the time Twain wrote "The Awful German Language" in 1879, some of his major works, including Tom Sawyer, had been published and he had established himself as major American literary figure. As a successful author and former newspaper reporter he had a keen eye for all matters of sentence structure and style. No wonder he analyzed this aspect of the German language with particular scrutiny.

His first comments concern sentence length, and there is no doubt that both $19^{\text {th }}$ century literary German and the German of the print media - it appears most of the texts he read were newspapers - contained excessively long sentences. They were also filled with parentheses, and it is the parenthesis that Twain mocks most intensely.

An average sentence...treats of fourteen or fifteen different subjects, each enclosed in a parenthesis of its own, with here and there extra parentheses with reenclose three or four of the minor parentheses, making pens within pens: finally, all the parentheses and reparentheses are massed together between a couple of king-parentheses, one of which is placed in the first line of the majestic sentence and the other in the middle of the last line of it - after which comes the VERB, and you find out for the first time what the man has been talking about (292). 
The parenthesis issue is one of the few where he makes explicit comparisons with English. His first and major approach to learning German employed constant comparisons with English and translation. He felt strongly enough about this point to criticize its manifestations in English.

We have the Parenthesis disease in our literature, too; and one may see cases of it every day in our books and newspapers: but with us it is the mark and sign of an unpracticed writer or a cloudy intellect, whereas with the German it is doubtless the make and sign of a practiced pen and of the presence of that sort of luminous intellectual fog which stands for clearness among these people. For surely it is not clearness, - it necessarily can't be clearness. Even a jury would have penetration enough to discover that. A writer's ideas must be a good deal confused, a good deal out of line and sequence, when he starts out to say that a man met a counsellor's wife in the street, and then right in the midst of this so simple undertaking halts these approaching people and makes them stand still until he jots down an inventory of the woman's dress. That is manifestly absurd (293).

Twain rounds off his parenthesis tirade with a general complaint on German word order and its core feature, the all too common sentence bracket. The case system allows greater internal word order freedom in German clauses, whereas it is relatively rigid in English. The latter has one main word order pattern, subject-verb-object; German employs two, the verb-second and the verb-final structure. Add to this the not insignificant 
number of separable prefix verbs in German and Twain is ready to abolish any kind of bracket or parenthetical structure in favor of a linear subjectverb-object sequence.

\section{Remarks on Lexical Features}

Twain devotes a portion of the essay to the vocabulary of German. He comments on the length, the meaning and the sound of many words. As he was on his own in the language learning process, he used the dictionary frequently. It is doubtful he had any guidance as to how to use a bilingual dictionary, an important step especially in the early phases of language learning. Few language instructors of today would have an advanced beginner or low intermediate level student -Twain's likely level at that time - consult a dictionary as extensively as he did. But Twain had very little instruction and we now nothing of its quality. He writes about the multiple meaning of many words - of course not an exclusive domain of German. He uses two examples: Zug and Schlag, and lists all the meanings provided by his dictionary. Despite his limited German proficiency he correctly identified a major difference between English and German lexical items. German makes semantic distinctions within a certain lexical field, e.g. the three verbs kennen, wissen, können have restricted uses, whereas the single 
English counterpart "to know" combines all these semantic distinctions into one verb. This does not mean that English has fewer alternatives to lexcial items. To the contrary. The vocabulary of English is considerably larger than that of German. Of course its vocabulary has restricted meanings too, but there is greater freedom in applying them. They don't always need to be selected (Hawkins 29). Twain puts it as follows:

The word Schlag means Blow, Stroke, Dash, Hit, Schock Clap, Slap, Time, Bar, Coin, Stamp, Kind, Sort, Manner, Way, Apoplexy, Wood-Cutting, Enclosure, Field, Forest-Clearing. This is its simple and exact meaning, - that is to say, its restricted, its fettered meaning; .... (298).

His next observation concerns compound nouns. Their sheer length sparked his curiosity and interest.

These things are not words, they are alphabetical processions. And they are not rare; one can open a German newspaper any time and see them marching majestically across the page, - and if he has any imagination he can see the banners and hear the music, too.... I take great interest in these curiosities (300).

The lack of hyphenation or breaking up in to multiple elements makes this issue even more difficult for the language learner. Twain correctly observed that the sky is the limit as far as the productivity of German compound words goes. New combinations can be created and they will not be found in 
the dictionary, as Twain noted. Some students of German find this productivity aspect of German word formation a positive one. It allows the speaker to create new words and play with language. Twain does not comment on this, perhaps, because he was so preoccupied with the receptive skills, especially reading comprehension, translation, to be exact. As in the case of the parenthesis, Twain makes a reference to English and argues against the encroachment of "the compounding disease" into English.

His final comment concerning lexical items is a more quirky, personal impression. Twain laments a lack of words whose sound reinforce their meaning, but only for one very narrow lexical situation, “...the description of any loud, stirring, tumultuous episode. Our descriptive words of this character have such a deep, strong, resonant sound, while their German equivalents do seem so thin and mild and energyless"(302). He attributes a more powerful effect to English one-syllable words such as 'boom, burst, crash, roar' and finds their German equivalents which are mostly polysyllabic, less forceful.

\section{"The Virtues of the Language" and "Suggestions for Reform"}

The mere presence of this section adds to the notion that "The Awful German Language" is more than just a humorous piece. It shows that Twain 
took a closer look at all aspects of the language. It is a quite short, but important and often overlooked section. Despite all his criticism, some aspects of German clearly fascinated him. It is the one section of the essay that is without satire.

His first point concerns the capitalization of nouns, which he considers a tremendous aid to the language learner. Secondly, he praises the sound -symbol correlation and criticizes its absence in English. Third, he comments on style:

The Germans do not seem to be afraid to repeat a word when it is the right one. They repeat it several times, if they choose. That is wise. But in English, when we have used a word a couple of times in a paragraph, we imagine we are growing tautological, and so we are weak enough to exchange it for some other word which only approximates exactness, to escape what we wrongly fancy is a greater blemish. Repetition may be bad, but surely inexactness is worse (303).

The far more common use of a thesaurus in English and the less frequent use of a dictionary of synonyms in German would - at least anecdotally support this view.

Lastly, he saves his strongest support for the descriptiveness of words. Twain once wrote: "The difference between the almost right word and the right word is really a large matter--it's the difference between the lightning bug and the lightning." Twain states, he was impressed by German 
"singularly and powerfully effective words" in five different areas: (1) "those which describe lowly, peaceful, and affectionate home life;" 2) "those which deal with love, in any and all forms" (3) "those which deal with outdoor Nature, in its softest and loveliest aspects...."(4) those which deal with any and all forms of rest, repose, and peace" (4) "those with deal with the creatures and marvels of fairyland" and (5) "lastly and chiefly, in those word which express pathos, is the language surpassingly rich and effective" (303). Twain does not provide any examples, but describes the emotional effect some of these words have on him: "That shows that the sound of the word is correct, - it interprets the meanings with truth and with exactness; and so the ear is informed, and through the ear, the heart" (303). After this brief, more serious treatment of the advantages of German, Twain fully returns to humor in his summarizing remarks, a list of suggested "reform measures" he would impose on German. He would mostly eliminate 'annoying' grammatical features, such as the dative case, verb-final position, grammatical gender with persons, long compound words and the parenthesis. 


\section{Conclusion: Twain's essay in the German language classroom}

There is an obvious danger inherent in any analysis of the essay "The Awful German Language.” It must inevitably fail to do justice to Twain's unique humor. Even though the humor carries the piece, it was not the focus of this article, and therefore much of it was not addressed. Let the following quote make up for this omission: "I heard a Californian Student in Heidelberg say, in one of his calmest moods, that he would rather decline two drinks than one German adjective" (294).

Twain's writings and many of his quotes continue to enjoy enormous popularity in the U.S. today. This brings up the question of how German language educators should treat this essay and Twain's German language learning experience. Should the essay be read and discussed, or should one steer clear of it as has been suggested (Patty 435)? Does it contribute to the image of German as a language that is impossible to master and thereby does more harm than good, or can it be used as a teaching tool? It appears that the profession has chosen the former over the latter. Few college textbooks mention Twain's essay, and if they do so, only in passing.

I would argue for dealing with Mark Twain in the German language classroom, as long as (1) the essay is placed in the appropriate context, (2) his methods of learning German are addressed, and (3) the significance of 
the German-speaking countries in Twain's life is illustrated. A good point would be the intermediate level when many learners often reach a frustrating plateau in the language learning process. Why not commiserate with one of America's foremost writers and get a good laugh at the same time? Twain did make a serious and prolonged effort at learning German and got genuinely frustrated in the process. Many learners go through similar frustrations and therefore can relate to his experience.

Let us examine each of the above-mentioned points. A classroom discussion of the essay itself needs to point out the significant changes, which written German has undergone since 1879. Twain would have welcomed these. There are fewer compound nouns of excessive length, far fewer parentheses and the dative singular noun marker -e has disappeared. Other simplifying changes are well on their way, such as the emerging main clause word order in weil clauses. Secondly, by today's standards, Twain learned German with poor methodology. Whether it is the intense focus on translation, excessive dictionary use, lack of listening and speaking practice, insistence on complete grammatical paradigms up front, Twain's language learning dilemma can be a lesson to instructors and can be used to show students what pitfalls to avoid. For example, the instructor can offset the gender of noun frustrations with the helpful item of gender identification by 
noun ending. Finally, despite all frustrations and disappointments, the entire Clemens family had an overall positive view of the culture of the German speaking countries. After all, they came back for many visits. The German language also left its mark on the Clemens family life. As late as 1909, Twain addressed his daughter Clara with the endearing term "Clärchen" and it is notable that the tombstone of Olivia, his wife of 34 years who died in 1904, and was an important 'sounding board' for the writer Twain, has the following German inscription: "Gott sei dir gnädig, O meine Wonne" (Krumpelmann 15). 


\section{References}

Hawkins, John A. A Comparative Typology of English and German:

Unifying the Contrasts. Austin, TX: University of Texas Press, 1986.

Kersten, Holger. "Mark Twain's First Joke on the German Language.” Mark Twain Journal, 31,1 (1993): 18-21.

Krumpelmann, John T. Mark Twain and the German Language. Baton Rouge: Louisiana State University Press, 1952.

Patty, Gabriele M. "'The Awful German Language,' Old English, and the Ethnocentric Student: A Backdoor Remedial Strategy." Monatshefte, 83,4 (1991): 433-438.

Thomas, Ursula. "Mark Twain's German Language Learning Experiences." Teaching German in America: Prolegomena to a History. Ed. David P. Benseler, Walter F.W. Lohnes and Walters Nollendorfs. Monatshefte Occasional Volume Number 7. Madison, Wisconsin: University of Wisconsin Press, 1988. 133-143.

Twain, Mark. "The Awful German Language." In: A Tramp Abroad. New York and London: Harper and Brothers Publishers, 1879. 290-307. 